Androniceanu, A.-M., Kinnunen, J., Georgescu, I., \& Androniceanu, A. (2020). A Multidimensional

Approach to Competitiveness, Innovation and Well-Being in the EU Using Canonical Correlation

Analysis. Journal of Competitiveness, 12(4), 5-21. https://doi.org/10.7441/joc.2020.04.01

\title{
A Multidimensional Approach to Competitiveness, Innovation and Well-Being in the EU Using Canonical Correlation Analysis
}

\author{
- Ane-Mari Androniceanu, Jani Kinnunen, Irina Georgescu, \\ Armenia Androniceanu
}

\begin{abstract}
Achieving a competitive economy and a competitive market generally proceeds from the desire to meet economic and social objectives and it ensures a growing level of social welfare. The objectives of our research are to determine and highlight the bidirectional linear correlations among competitiveness, well-being and innovation and to analyze the main factors that influence these relations. Our research includes the EU member states and the UK using these countries' specific indicators from the databases of EUROSTAT, the World Economic Forum and the United Nations from 2016-2018. We used Canonical Correlation Analysis to determine a set of canonical variates which represent linear combinations of the variables from each set. The contributions of our research show a direct and strong link among the three pillars of competitiveness, innovation and well-being. This analysis allowed us to identify and analyze the influence of innovation on the economic development and competitiveness of each EU country and on the well-being of its population. Governments and organizations that invest more in research in terms of innovation to increase the competitiveness of their products and services have shown a growing GDP and a higher level of population well-being. This research is representative at the European level and may influence the decisions of national governments and other institutions to encourage innovation through drivers such as $\mathrm{R} \& \mathrm{D}$ expenditures and human resources as the main factors generating economic growth and competitiveness, thus with a direct effect on GDP and on well-being.
\end{abstract}

Keywords: competitiveness, innovation, well-being, HDI, GDP

JEL Classification: F63, O10, O31, O33, Q 55

Received: July, 2020

1st Revision: November, 2020

Accepted: November, 2020

\section{INTRODUCTION}

Globally there is an increase in the intensity of competitiveness in the context of accelerating globalization, the development of information and communication technologies, and an increase in the number of innovations in the economic, technological and service fields. It is clear that national economies require a change in their model of economic development (Shkolnyk et al., 2019). The need to adapt the economies of states is a reality that cannot be neglected. Economic 
competitiveness analyzed at the country level describes the ability of an economy to provide the population with a high standard of living and a degree of employment on a sustainable basis (Fyliuk et al., 2019; Haller, 2020). The level at which competitiveness is generated is microeconomic (Balkyte \& Tvaronaviciene, 2010; Ključnikov et al., 2016; Kozubikova et al., 2019; Wenzel \&Wolf, 2016; Leković et al., 2019; Olšovská et al., 2016; Altun \& Çelik, 2020). Well-being is undoubtedly a multidimensional concept, as it includes many aspects of human life, not just those related to income or consumption (Meyer et al., 2017). Such aspects include, among others, health, education, income, equality and environmental conditions, as described in the inequalityadjusted Human Development Index (IHDI) (UNDP, 2019b) and Global Competitiveness Index (GCI) (Mishchuk \& Grishnova, 2015; Vasilyeva et al., 2018; Schwab, 2019). The standard of living represents the level of wealth, comfort, material goods and indispensable goods available to a certain socio-economic class or a certain geographical area. Factors enabling well-being and economic growth range from population growth, working hours, technology, specialization, capital, labor and productivity as well as among various institutional factors such as political systems and economic freedom and development (CORE, 2017; Cieślik \& Michałek, 2018; Belas et al., 2018; Kinnunen et al., 2019; Schwab, 2019; Belas et al., 2020). In a previous studies of ours, we applied a Canonical Correlation Analysis (CCA) for 2018-2019 to study the progress of digital skills and their impact on the well-being, income inequality and competitiveness of world countries (Georgescu \& Kinnunen, 2020) as well as on the labor force (Androniceanu et al., 2020). Dos Santos \& Brandi (2014) have applied CCA to study the intracorrelations and the intersections between competitiveness and environmental sustainability for 17 countries.

In this paper, the authors seek to approach the above issues in an original way through the bidirectional linear correlations among competitiveness, innovation and well-being. The research highlights how each country positions itself in regard to these factors as well as how competitiveness and innovation influence the well-being of European citizens. Based on the research results, a new relationship has been described between the competitiveness in EU countries and the impact on well-being using CCA.

\section{THEORETICAL BACKGROUND}

Although research on competitiveness has advanced, there is still no unanimously accepted definition nor is there a universal and complete theory of national competitiveness. This lack of concrete definiton is related to the complexity and multidimensionality of these categories and to the practice of applying them at different levels of the economy (Lukiewska, 2019). The literature reveals extremely varying perspectives in defining, measuring and understanding competitiveness, i.e. the concept has been engaged using a multitude of different approaches (Calantone \& di Benedetto, 1990; Vetráková \& Smerek, 2019). In the view of Porter (1998), the only comprehensive indicator can define the concept of competitiveness at the national level is national productivity. According to the OECD, competitiveness is the ability to produce goods and services that can compete internationally while maintaining and increasing real domestic income. In the opinion of the Management Forum 2019, global competitiveness represents the ability of the country or company to proportionately generate more prosperity than its competitors on the international market.

The notion of competitiveness itself has been used in various senses and on multiple levels, i. e. in 
various business sectors, for example, tourism (Kelić et al., 2020), services (Dvorský et al., 2020), as well as SMEs (Čepel, 2019). The Diamond Model developed by Porter focuses on the factors that determine international competitiveness but which operate at the microeconomic level. Porter (1985) completed the original model, adding two exogenous factors: chance and government. In the present authors' opinion, competitiveness is a concept that describes the ability of a national/ international economy to cope with competition in the market by increasing economic efficiency and social welfare. A number of approaches to competitiveness have been presented in the literature: (1) one based on the theory of comparative advantage (Mura et al., 2015); (2) from the perspective of strategies and management; (3) from a historical and socio-cultural perspective; as well as (4) from the perspective of competitive advantage (which takes into account other factors more difficult to measure: technological level, innovation, product quality, including after-sales services) (Zeibote et al., 2019; Brodowska-Szewczuk, 2019; Caurkubule et al., 2020); (5) from the perspective of sustainable development, given the imperative of ensuring long-term global development by intensifying efforts to protect the environment, i.e. the rational use of non-renewable resources (Piątkowski, 2020; Bilan et al., 2020; Streimikiene, 2014).

Other economic competitiveness models include: (1) The World Economic Forum Model; (2) The European Model and (3) The Model of Michael Porter. The World Economic Forum model is based on: (1) the Growth Competitiveness Index and (2) the Business Competitiveness Index, which has been replaced by the (3) Global Competitiveness Index followed by (4) The New Global Competitiveness Index. The European Model is based on highlighting the fulfillment of the criteria of the Lisbon Strategy and the Europe 2020 Strategy covering six areas and over 100 indicators related to: General Economic Base; Employment; Innovation and Research; Economic Reform; Social Cohesion; and Environment.

From the present authors' point of view, the most important goal of competitiveness is the well-being of a nation, with the degree of achievement regarding this factor the best measure of competitiveness, i. e. as reflected in GDP in terms of facilitating developments in other societal areas (Cannas et al., 2019; Trettin et al. 2019; Vlacseková \& Mura, 2017). Well-being is a complex concept, one frequently used in many disciplines ranging from philosophy and psychology to sociology and economics. Although there is no generally accepted definition, as it is still quite difficult to define the notion given large number of varying interpretations, one possible approach is to define well-being as a description of the real situation of people's lives. The authors view the well-being and happiness of a nation as arising primarily from the ability of its economy to be competitive. Competitiveness is influenced by many factors. One of most important parameters increasing the competitiveness and, thus, the well-being of a country's population is innovation (Nica, 2019; Piątkowski et al., 2020). Schumpeter (1934) distinguishes five types of innovation: new products, new production methods, the exploitation of new markets, new methods of offering products on the market, and new ways of organizing business (Felstead, 2019). In turn, Schmookler (1966) differentiates the "technological product" from the "technological production", in terms of how products are created or improved and, respectively, depending on how they are produced (Schmookler, 1966; Pavitt, 1984; Bloch, 2007; Janoskova \& Kral, 2019; Kaplan \& Norton, 1992; Razavi et al., 2011). Eco-innovation is a new term with significance through the more favorable impact exerted on the environment by production processes or through the use of goods. The term was first used by Fussler \& James (1996) referring to the new products and processes that provide value to customers and businesses, while significantly reducing the 
impact on the environment, presenting with a similar meaning "environmental innovation", “innovation for sustainable development" or "sustainable innovation" (Šloga \& Bezić, 2020). As numerous practical examples from industry demonstrate, eco-innovation is a powerful instrument that combines a reduced negative impact on the environment with a positive impact on the economy and society (Mikiashvili \& Lobzhanidze, 2017) that, in addition, can contribute to a competitive economy (Johnson \& Kaplan, 1987; Jašková, 2019; Sebestova \& Sroka, 2020; Wasiluk \& Ginevičius, 2020). We focus our research on the correlation between competitiveness, innovation and well-being, using a set of specific indicators (Fyliuk et al., 2019) and Canonical Corrrelation Analysis (Kachigian, 1991; Sharma, 1996; Jafarnejad Chaghooshi et al., 2015).

\section{RESEARCH OBJECTIVE, METHODOLOGY AND DATA}

The aim of our research is to identify a new relationship between the competitiveness and innovation in the EU countries and their impact on well-being by applying Canonical Correlation Analysis (CCA). The data under analysis is collected for the years 2016-2018 for 27 European Union countries plus the United Kingdom, which was an EU memberstate during the research period. The data used consists of 10 variables: V1 - GCI - Global Competitiveness Index 4.0 - A survey-based index built on 12 pillars: institutions, infrastructure; ICT adoption, macroeconomic stability, health, skills, product market, labor market, financial system, market size, business dynamism, and innovation capability (World Economic Forum, 2019; Schwab, 2019); V2 - IHDI - built on 3 pillars: health, education and income adjusted to the level of inequality (UNDP, 2019a; 2019b); V3 - GDP per capita in terms of purchasing power standards, PPS, where EU average is set to 100 (Eurostat, 2019); V4 - Real GDP 1-year growth rate (Eurostat, 2019); V5 Overall 1-year employment growth, \% (Eurostat, 2019); V6 - GORD - Gross domestic expenditure on R\&D as \% of GDP (Eurostat, 2019); V7 - Patent applications per million inhabitants (Eurostat, 2019); V8 - HRST - Human resources in science and technology, i.e. share of people having completed an education at the third level or being employed in science and technology as a percentage of total active population aged 25-64 (Eurostat, 2019); V9 - "Knowledge workers", i.e. employment in high/medium technology and knowledge-intensive sectors as \% of total employment (Eurostat, 2019); V10 - Labor productivity per person employed and hour worked; index, where the average of EU27 in 2020 is 100 (Eurostat, 2019). CCA is a multivariate data reduction technique introduced in 1936 by Hotelling to model the relationship between two sets of variables. Linear combinations of variables which maximally correlate are discovered. The data dimensionality is reduced by determining a set of canonical variates which are linear combinations of the variables from each set (the dependent and the independent ones) that explain the variability between and within the two sets. The number of dimensions (canonical functions) equals the number of variables in the smallest set. The canonical variates represent relationships between the dependent and the independent sets. The CCA model consists of five dependent variables, V1-V5, and five independent variables, V6-V10 of which V1-V5 are the features of competitive well-being and V6-V10 are the features of innovation resources (Figure 1). The model predicts the dependent variables, GCI, IHDI, GDP per capita, Real GDP growth and the Overall employment growth by the independent variables: R\&D expenditure, Patent applications, HRST, Employment in high- and medium-high technology manufacturing sectors and knowledge-intensive service sectors and Labor productivity. The indicators are separated into two classes: the set $\mathrm{X}$ of competitive well-being and the set $\mathrm{Y}$ of innovation resources as seen in 
Figure 1. The competitive well-being framework designed by the authors the overlaps OECD's (2017) well-being framework, where resources are required for sustainable well-being, while in our approach, innovation resources build competitive well-being.

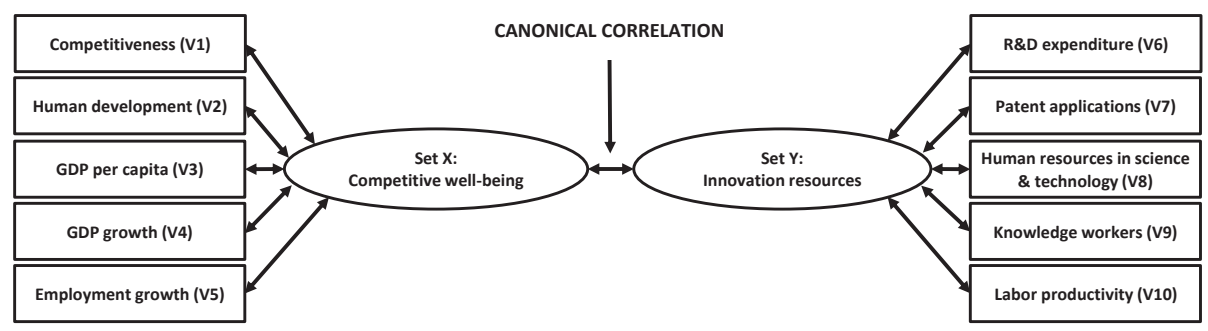

Fig. 1- Canonical correlation framework. Source: own research

There is applied CCA to the sets $X$ and $Y$. These are recalled the dependent set and the independent set $Y=\left(V_{6}, \ldots, V_{10}\right)^{T}$. There are the five pairs of canonical variates $\left(A_{i}, B_{i}\right), i=1, \ldots, 5$ of the model. $A_{i}$ is written as a linear combination of the elements of set $X$ and $B_{i}$ of the elements of set $Y$ as follows:

$A i=a_{i 1} V_{1}+\ldots+a_{i 5} V_{5}, i=1, \ldots, 5$
$B i=b_{i 1} V_{6}+\ldots+b_{i 5} V_{10}, i=1, \ldots, 5$

The aim of CCA is to find the linear combination that maximizes the canonical correlation for the canonical pairs $\left(A_{i}, B_{i}\right), i=1, \ldots, 5$ using equations (1) and (2). The canonical correlation between the $i$-th canonical pair $\left(A_{i}, B_{i}\right), i=1, \ldots, 5$ is

$\varrho_{i}^{*}=\left(\operatorname{cov}\left(A_{i}, B_{i}\right)\right) / \sqrt{ }\left(\operatorname{var}\left(A_{i}\right) \operatorname{var}\left(B_{i}\right)\right)$.

The main steps of CCA are: (i) to determine if there is any relationship between the two sets of variables. By Wilks's lambda, we reject the null hypothesis that there is no relationship between the two sets and conclude that they are dependent; (ii) the null hypothesis from above is equivalent to the null hypothesis that all 5 canonical variate pairs are not correlated: $\mathrm{H} 0: \varrho_{1}{ }^{*}=\ldots=\varrho_{5}{ }^{*}=0$. Wilks's lambda is significant and the canonical correlations are in a decreasing order, therefore, we conclude that at least $\varrho 1^{*} \neq 0$. Successively, we find that the first four canonical pairs are correlated and the fifth one is not; (iii) to interpret each canonical variable, we compute the correlation between each variable and the corresponding canonical variate; (iv) finally, we find the best predictors for each variable in the dependent set.

\section{RESULTS AND DISCUSSION}

Figure 2 shows the statistically significant correlations within set $\mathrm{X}$ on the left and within set $\mathrm{Y}$ on the right side of the figure. 

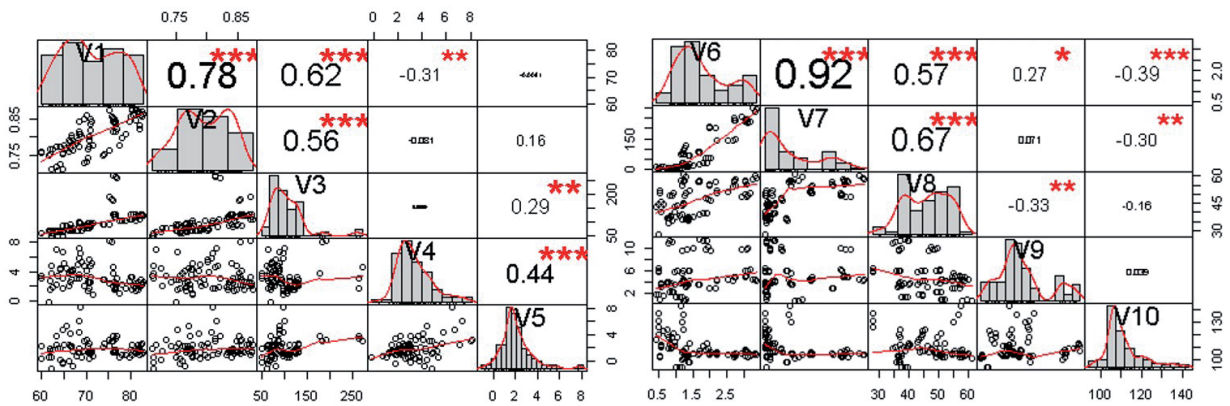

Fig. 2 - Correlations: within set $X$ (left) and within set $Y$ (right). Source: own research

From the left side of Figure 2, we can note that the highest correlations are seen between GCI (V1) and IHDI (V2) and GDP per capita ranging from 0.78 (V1 vs. V2), 0.62 (V1 vs. V3) to 0.56 (V2 vs. V3), while Employment growth (V5) is significantly, but less strongly correlated with the GDP growth (V4) and GDP per capita (V3) by the factor of 0.44 and 0.29 , respectively. There is one negative correlation within set X: GDP growth (V4) and GCI (V1) are correlated by the factor of -0.31. Some countries with the weakest competitiveness index of the EU countries, such as Romania, Cyprus, Hungary, Bulgaria and Croatia with an average GCI ranging from 60.73 to 65.55 (EU$28 \mathrm{avg}=71.96)$ have shown a stronger GDP growth from 2016 to 2018, ranging from Croatia's $3.10 \%$ to Romania's $5.43 \%$ (EU28avg $=3.23 \%$ ). From the right side of Figure 2, we can note that R\&D expenditure (V6) correlates almost perfectly with patent applications (V7) by the factor of 0.92. Other strong correlations are seen between R\&D expenditure (V6) and HRST (V8) of 0.57, and between patent applications and V8 of 0.67 . R\&D expenditure is further positively correlated (0.27) with "knowledge workers", i.e. people employed in high-tech and knowledge-intensive services (V9). There are some negative correlations within set Y: labor productivity (V10) correlates negatively (-0.39) with R\&D expenditures (V6) and by - 0.30 with patent applications (V7). For example, Romania and Bulgaria are relatively strong as for their productivity, but low in R\&D expenditures as a share of GDP. Also, high-technology and knowledge-intensive employment share to all employed (V9) correlates by - 0.33 with HRST. For example, Hungary, Slovenia, Slovakia and the Czech Republic show high-level share of employed knowledge workers, while their HRST as a share of the whole population is not particularly high. Pillai's trace test, Hotelling's trace test, Wilks's lambda multivariate criteria are significant, with $\mathrm{p}<0.05$, proving that there is a statistically significant and positive linear relationship between the dimensions of innovation and well-being indicators. The CCA analysis generated 5 roots, as can be seen in Table 1 .

Tab. 1 - Eigenvalues and canonical correlations. Source: own research

\begin{tabular}{|l|l|l|l|l|l|}
\hline Root No. & Eigenvalue & Pct. & Cum. Pct. & Canon Cor. & Sq. Cor \\
\hline 1 & 11.23720 & 83.26339 & 83.26339 & .95827 & .91828 \\
\hline 2 & 1.43805 & 10.65542 & 93.91881 & .76801 & .58984 \\
\hline 3 & .49783 & 3.68874 & 97.60755 & .57651 & .33237 \\
\hline 4 & .32023 & 2.37275 & 99.98030 & .49250 & .24255 \\
\hline 5 & .00266 & .01970 & 100.00000 & .05149 & .00265 \\
\hline
\end{tabular}


The roots rank the eigenvalues in a decreasing order. Canonical correlations represent Pearson correlations of the pairs of canonical variates. The first canonical correlation, 0.95827 , represents the correlation coefficient between the first pair of canonical variates. $91.82 \%$ of the variation in is explained by the variation in ; $58.98 \%$ of the variation in is explained by the variation in , etc. We will retain these two higher values, considering that the first two canonical correlations are the most significant. In Table 2, we test the null hypothesis that all correlations associated with the roots are equal to 0 . The first test shows that all five canonical roots combined are significant, since p-value $=0<0.05$. Similarly, the next 3 tests prove that roots 2 to 5,3 to 5 and 4 to 5 are significant, since $\mathrm{p}$-value $=0<0.05$. The last test is not significant, since $\mathrm{p}=0.650>0.05$.

Tab. 2 - Dimension reduction analysis. Source: own research

\begin{tabular}{|l|l|l|l|l|l|}
\hline Roots & Wilks L. & F & Hypoth. DF & Error DF & Sig. of F \\
\hline 1 TO 5 & .01690 & 22.10299 & 25.00 & 276.40 & .000 \\
\hline 2 TO 5 &, 20687 & 9,69201 & 16,00 & 229,77 &, 000 \\
\hline 3 TO 5 &, 50435 & 6,68013 & 9,00 & 185,11 &, 000 \\
\hline 4 TO 5 &, 75544 & 5,79567 & 4,00 & 154,00 &, 000 \\
\hline 5 TO 5 &, 99735 &, 20734 & 1,00 & 78,00 &, 650 \\
\hline
\end{tabular}

Next, we determined the raw canonical coefficients and correlations for the dependent variables in Table 3 and the independent variables in Table 5.

Tab. 3 - Canonical coefficients and correlations: dependent. Source: own research

\begin{tabular}{|l|l|l|l|l|l|}
\hline Canonical coefficients & 1 & 2 & 3 & 4 & 5 \\
\hline V1 & -.06198 & -.00319 & -.04126 & -.17939 & -.20653 \\
\hline V2 & -13.15815 & -3.11806 & 17.17876 & 24.57487 & 12.58762 \\
\hline V3 & -.00090 & -.00293 & -.01975 & -.00215 & .02502 \\
\hline V4 & -.01425 & -.68362 & -.04611 & -.12122 & -.21488 \\
\hline V5 & .06197 & .43643 & -.33889 & .39782 & -.48273 \\
\hline Canonical correlations & 1 & 2 & 3 & 4 & 5 \\
\hline V1 & -.92160 & .13013 & -.13807 & -.30218 & -.15277 \\
\hline V2 & -.95596 & -.04366 & .05769 & .28282 & .03038 \\
\hline V3 & -.61949 & -.04503 & -.70082 & -.02667 & .34979 \\
\hline V4 & .19490 & -.84037 & -.26923 & .32730 & -.27601 \\
\hline V5 & -.03011 & .06305 & -.62384 & .64850 & -.43057 \\
\hline
\end{tabular}

The raw canonical coefficients are interpreted as in the linear regression models, considering the canonical variates as outcome variables. For example, a one-unit increase in variable V1 GCI leads to a 0.06198 decrease in the first variate of competitiveness and well-being measurement (top of Table 3). The first canonical variable for competitiveness and well-being (bottom of Table 3) is negatively strongly dominated by V1 GCI with a canonical correlation of -0.92160 and V2 IHDI, with a correlation of -0.95596 . The second canonical variable for competitiveness and 
well-being is strongly negatively dominated by V4 real the GDP growth rate with a correlation of -0.84037. As for the remaining canonical variables for competitiveness and well-being, none of the correlations are sufficiently large, therefore, these canonical variables yield little information about the data. In Table 4, 43.71\% of the variance among the dependent set of competitiveness and well-being is explained by the first dependent canonical variate. Similarly, $14.62 \%$ of the variance among competitiveness and well-being is explained by the second one.

Tab. 4 - Variates' variance explained by canonical variables. Source: own research

\begin{tabular}{|l|l|l|l|l|}
\hline Can. Var & PctVar DEP & Cum Pct DEP & PctVarCOV & Cum PctCOV \\
\hline 1 & 43.71732 & 43.71732 & 40.14483 & 40.14483 \\
\hline 2 & 14.62130 & 58.33862 & 8.62418 & 48.76900 \\
\hline 3 & 19.50385 & 77.84247 & 6.48246 & 55.25146 \\
\hline 4 & 13.99399 & 91.83645 & 3.39429 & 58.64576 \\
\hline 5 & 8.16355 & 100.00000 & .02164 & 58.66740 \\
\hline
\end{tabular}

A one-unit increase in variable V6 R\&D expenditure leads to a 0.01005 increase in the first variate of innovation measurements described by canonical coefficients in Table 5. In Table 5. the first canonical variable for innovation is strongly dominated by V6. R\&D expenditure, with a canonical correlation of -0.84909 V7 Patent applications (-0,98947) and V8 HRST (-0.83573). The second canonical variable for innovation is strongly negatively dominated by V10, Labor productivity. As for the other canonical variables for innovation, the correlations are small, thus they yield little information about the data.

Tab. 5 - Canonical coefficients and correlations: independent. Source: own research

\begin{tabular}{|l|l|l|l|l|l|}
\hline Canonical coefficients & 1 & 2 & 3 & 4 & 5 \\
\hline V6 & .01005 & .02737 & 2.25564 & -1.17588 & 2.82106 \\
\hline V7 & -.00425 & .00145 & -.01346 & -.00462 & -.02915 \\
\hline V8 & -.08248 & -.03826 & -.07288 & .12911 & .06426 \\
\hline V9 & -.13304 & -.06813 & .03427 & .39724 & -.23245 \\
\hline V10 & -.00381 & -.10169 & .02976 & -.05590 & .01991 \\
\hline Canonical correlations & 1 & 2 & 3 & 4 & 5 \\
\hline V6 & -.84909 & .28312 & .36209 & -.26008 & .01193 \\
\hline V7 & -.87947 & .21516 & .04770 & -.37492 & -.19337 \\
\hline V8 & -.83573 & -.00415 & -.43560 & -.04956 & .33065 \\
\hline V9 & -.18166 & -.11292 & .75274 & .47547 & -.40194 \\
\hline V10 & .18031 & -.97193 & .00848 & -.14001 & -.05635 \\
\hline
\end{tabular}

Table 6 shows that $41.47 \%$ of the variance among the innovation set is explained by the first independent canonical variate, while $12.78 \%$ is explained by the second one. 
Tab. 6 - Covariates' variance explained by canonical variables. Source: own research

\begin{tabular}{|l|l|l|l|l|}
\hline & PctVar DEP & Cum Pct DEP & PctVarCOV & Cum PctCOV \\
\hline 1 & 41.47683 & 41.47683 & 45.16786 & 45.16786 \\
\hline 2 & 12.78597 & 54.26280 & 21.67713 & 66.84499 \\
\hline 3 & 5.91497 & 60.17777 & 17.79643 & 84.64142 \\
\hline 4 & 2.21369 & 62.39146 & 9.12661 & 93.76803 \\
\hline 5 & .01652 & 62.40798 & 6.23197 & 100.00000 \\
\hline
\end{tabular}

In Table 7, the regression results of the effect of the innovation indicators on each competitiveness and well-being indicator are presented. The beta value measures the importance of each covariate for each dependent variable.

Tab. 7 - Regression analysis for cells error term. Source: own research

\begin{tabular}{|c|c|c|c|c|c|c|c|}
\hline \multicolumn{8}{|c|}{ Dependent variable: GCI (V1) } \\
\hline Covariate & $\mathrm{B}$ & Beta & Std. Err. & $\mathrm{t}$-Value & Sig. of $\mathrm{F}$ & Lower $-95 \%$ & CL- Upper \\
\hline V6 & -.222 & -.029 & 1.237 & -.180 & .858 & -2.68 & 2.240 \\
\hline $\mathrm{V7}$ & .040 & .546 & .0107 & 3.727 & .000 & .019 & .0610 \\
\hline V8 & .372 & .476 & .0604 & 6.160 & .000 & .252 & .492 \\
\hline V9 & .342 & .149 & .158 & 2.165 & .033 & .028 & .656 \\
\hline V10 & -.0067 & -.010 & .040 & -.171 & .865 & -.086 & .072 \\
\hline \multicolumn{8}{|c|}{ Dependent variable: IHDI (V2) } \\
\hline Covariate & B & Beta & Std. Err. & t-Value & Sig. of $\mathrm{F}$ & Lower $-95 \%$ & CL- Upper \\
\hline V6 & -.004 & -.082 & .008 & -.589 & .558 & -.020 & .0107 \\
\hline V7 & .000 & .251 & .000 & 1.959 & .054 & .000 & .0003 \\
\hline V8 & .004 & .800 & .000 & 11.810 & .000 & .004 & .005 \\
\hline V9 & .009 & .530 & .000 & 8.797 & .000 & .007 & .011 \\
\hline V10 & .000 & .001 & .000 & .0273 & .978 & -.000 & .000 \\
\hline \multicolumn{8}{|c|}{ Dependent variable: GDP per capita (V3) } \\
\hline Covariate & $\mathrm{B}$ & Beta & Std. Err. & $\mathrm{t}$-Value & Sig. of F & Lower $-95 \%$ & CL- Upper \\
\hline V6 & -36.503 & -.737 & 12.802 & -2.851 & .006 & -61.990 & -11.015 \\
\hline V7 & .319 & .691 & .110 & 2.891 & .005 & .099 & .539 \\
\hline V8 & 3.393 & .685 & .625 & 5.430 & .000 & 2.149 & 4.637 \\
\hline V9 & 2.489 & .171 & 1.635 & 1.522 & .132 & -.767 & 5.744 \\
\hline V10 & -.221 & -.049 & .410 & -.539 & .591 & -1.036 & .595 \\
\hline \multicolumn{8}{|c|}{ Dependent variable: GDP growth (V4) } \\
\hline Covariate & $\mathrm{B}$ & Beta & Std. Err. & $\mathrm{t}$-Value & Sig. of $\mathrm{F}$ & Lower $-95 \%$ & CL- Upper \\
\hline V6 & -.986 & -.515 & .503 & -1.961 & .053 & -1.988 & .015 \\
\hline V7 & .000 & .003 & .004 & .011 & .991 & -.009 & .009 \\
\hline V8 & .067 & .350 & .025 & 2.732 & .008 & .018 & .116 \\
\hline
\end{tabular}




\begin{tabular}{|l|l|l|l|l|l|l|l|}
\hline V9 & .134 & $\mathbf{. 2 3 9}$ & .064 & 2.092 & $\mathbf{. 0 4 0}$ & .007 & .262 \\
\hline V10 & .084 & $\mathbf{. 4 8 5}$ & .016 & 5.252 & $\mathbf{. 0 0 0}$ & .052 & .117 \\
\hline \multicolumn{7}{|l|}{ Dependent variable: Employment growth } & (V5) \\
\hline Covariate & B & Beta & Std. Err. & t-Value & Sig. of F & Lower -95\% & CL- Upper \\
\hline V6 & -1.776 & $\mathbf{- 1 . 0 8 0}$ & .535 & -3.318 & $\mathbf{. 0 0 1}$ & -2.841 & -.710 \\
\hline V7 & .006 & .390 & .005 & 1.297 & .199 & -.003 & .0152 \\
\hline V8 & .095 & $\mathbf{. 5 7 5}$ & .0261 & 3.624 & $\mathbf{. 0 0 1}$ & .0423 & .147 \\
\hline V9 & .171 & $\mathbf{. 3 5 4}$ & .068 & 2.503 & $\mathbf{. 0 1 4}$ & .035 & .307 \\
\hline V10 & -.048 & $\mathbf{- . 3 2 2}$ & .017 & -2.810 & $\mathbf{. 0 0 6}$ & -.082 & -.014 \\
\hline
\end{tabular}

Based on the Beta values from Table 7, we have reached the following conclusions:

- The effect of Patent applications per million inhabitants (V7) is more important than the effect of HRST (V8) and Employment in high- and medium-high technology manufacturing sectors and knowledge-intensive service sectors (Knowledge workers, V9) in predicting GCI (V1).

- The effect of HRST (V8) is more important than the effect of employment share of knowledge workers (V9) in predicting IHDI (V2), while V6 and V7 were statistically insignificant.

- The effect of R\&D expenditure (V6) is more important in absolute value than the effect of Patent applications (V7) and HRST (V8) in predicting GDP per capita (V3). The negative beta of V6 suggests that larger the GDP (V3), the smaller share of it is directed to R\&D.

- The effect of Labor productivity per person employed and hour (V10) is more important than the effect of R\&D expenditure (V8) and HRST (V9) in predicting GDP growth (V4).

- The effect of R\&D expenditure (V6) is more important in absolute value than the effect of HRST (V8), Knowledge workers (V9) and Labor productivity (V10) in predicting the Overall employment growth (V5). The effects of R\&D expenditures (similarly in predicting GDP per capita) and Labor productivity are negative. The negative betas of V6 and V10 suggest rather counter intuitively that the larger the share of R\&D expenditures of GDP and the higher the labor productivity, the lower the employment growth in EU in 2016-2018. This is due to asymmetric effects: some countries have very high values in some variables, but do poorly in another aspect, e.g. Romania, Bulgaria and Latvia are the 2nd-4th most labor-productive countries with the average employment growth of $0.5 \%, 0.73 \%$ and $0.43 \%$, respectively, while the EU average is $1.91 \%$ (cf. their R\&D expenditures as a share of GDP are $0.49 \%, 0.76 \%$ and $0.53 \%$, respectively), and Malta and Cyprus, while at the bottom level in R\&D expenditures, have the highest employment growth of $6.13 \%$ and $4.70 \%$, respectively.

The main findings from the bidirectional canonical correlation analysis are summarized in Figure 3. The constructed 1 st canonical variable was able to explain $43.72 \%$ (cf. Table 4 ) of the total variance of the dependent variables V1-V5 characterizing the competitive well-being set X. Similarly, the 1 st canonical variable explained $41.48 \%$ (cf. Table 6 ) of the total variance of the independent variables of the innovation set $\mathrm{Y}$. The 1 st root, i.e., the 1stcanonical correlation of 0.958 , falls between the first pair of canonical variates from set $\mathrm{X}$ and set $\mathrm{Y}$ (A1, B1) based on equations (1) and (2). This means that $83.26 \%$ of the variation in is explained by the variation in (Table 1). 


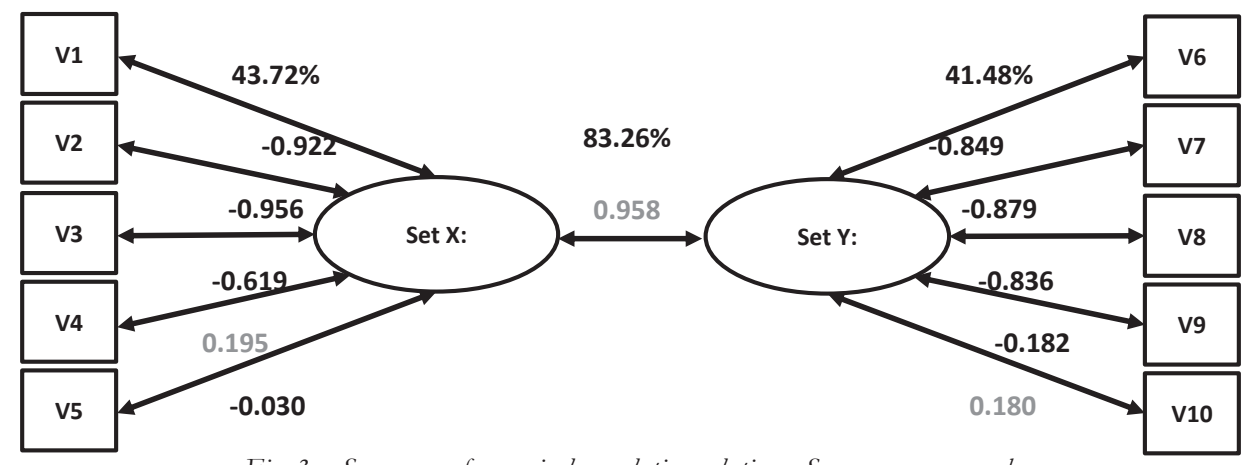

Fig. 3 - Summary of canonical correlation relations. Source: own research

The individual canonical correlations between the dependent variables V1-V5 and the competitive well-being set $\mathrm{X}$ in Figure 3 (Table 3) show: GCI (V1) correlates with set X by a factor of -0.922; IHDI (V2) by -0.956; GDP per capita (V3) by -0.619; and small correlations between competitive well-being and the GDP growth (V4) as well as Employment growth (V5), 0.195 and -0.030 , respectively. The individual canonical correlations show strong correlations between the competitive well-being set $\mathrm{X}$ and the independent variables V6 (R\&D expenditure as a share of GDP), V7 (Patent applications), and V8 (HRST), -0.849, -0.879 and -0.836, respectively, while small correlations are seen with V9 (Employed high-technology and knowledge-intensive workers) and V10 (Labor productivity), -0.182 and 0.180, respectively (cf. Table 5). Based on CCA, the set $\mathrm{X}$ variables (except for the GDP growth, V4) are positively linked to the set $\mathrm{Y}$ variables (except the Labor productivity, V10).

\section{CONCLUSION}

CCA was conducted on EU-28 countries in 2016-2018 using a set of five indicators for competitive well-being and another set of five indicators for innovation resources. By using CCA, we have determined possible dependencies of two phenomena which are represented by number of features. The features of innovation were selected from the Eurostat database based on our judgement to best capture the perspectives of innovation resources (Jašková, 2019; Johnson \& Kaplan, 1987; Razavi et al., 2011; Sebestova \& Sroka, 2020; Wasiluk \& Ginevičius, 2020; Popescu G.H. \& Ciurlău). Our well-being framework overlaps the OECD’s (2017) sustainable well-being framework: HDI (V2) captures health and education pillars, which together with the employment growth (V5), represent the OECD's quality-of-life perspective, while GDP per capita (V3) and the GDP growth (V4) represent the material well-being perspective. Competitiveness (V1) is seen analogously with the OECD's sustainability in the sense that competitiveness sustains well-being by supporting GDP growth and economic development through profitable competitive transactions in global markets (Schwab, 2019; Bilan et al., 2020; Belas et al., 2018; Belas et al., 2020; Cieślik \& Michałek, 2018). Direct links were found from the latter to the first set: canonical correlations showed strong links from R\&D expenditures, patent applications and HRST to competitiveness, GDP per capita and IHDI built on national levels of education, health and income. During the three-year research period, competitiveness obtained the greatest weight of 
the competitive well-being indicators. Thus, competitiveness was clearly the key factor to sustain the well-being of EU nations, a finding in line with our presumptions. Further, some counterintuitive asymmetries between the EU countries were noted. For example, labor productivity per worked hours and real GDP growth rate were negatively correlated with other indicators. However, labor productivity was negatively related only to the employment growth in a statistically significant manner, while the latter was assigned with the smallest weight of the well-being features of the EU countries.

The limitations of this research reside in the fact that it was a short-run analysis of the dependence relation between competitive well-being and innovation. The complex nature of both the competitive well-being and innovation realm are linked to a wide range of factors out of the scope of this study. For example, the phase of an economic cycle, economic policies of governments as well as EU-level strategies change over time and, thus, using data from a period other than the recent years 2016-2019 of this study may produce different dependencies. To establish stable causal links over time, future research can be extended to a long-run analysis applying CCA in a time series (Akaike, 1976; Cao et al., 2019) and testing Granger causality.

\section{References}

1. Akaike, H. (1976). Canonical Correlation Analysis of time series and the use of an information criterion. Mathematics in Science and Engineering, 126, 27-96.

2. Altun, A. \& Çelik, B., (2020). The relationship between "innovation, science and technology" and "economic development": canonical correlation analysis for the EU countries. International Journal of Social Sciences, 78 (1), 27-34.

3. Androniceanu, A. M., Georgescu, I., Tvaronavičiené, M., \& Androniceanu, A. (2020). Canonical Correlation Analysis and a new composite index on digitalization and labor force in the context of the Industrial Revolution 4.0. Sustainability, 12 (17), 6812. https://doi.org/10.3390/su12176812

4. Balkyte, A., \& Tvaronaviciene, M. (2010). Perception of competitiveness in the context of sustainable development: facets of "sustainable competitiveness. Journal of Business Economics and Management, 11 (2), 341-365. https://doi.org/10.3846/jbem.2010.17

5. Belas, J., Gavurova, B. \& Toth, P. (2018). Impact of selected characteristics of SMEs on the capital structure. Journal of Business Economics and Management, 19 (4), 592-608.

6. Belas, J., Kmecová, I. \& Cepel, M. (2020). Availability of human capital and the development of the public infrastructure in the context of business activities of SMEs. Administratie si Management Public, 34, 27-44. https://doi.org/10.24818/amp/2020.34-02

7. Bilan, Y., Hussain, H. I., Haseeb, M. \& Kot, S. (2020). Sustainability and economic performance: role of organizational learning and innovation. Engineering Economics, 31 (1), 93-103. https://doi.org/10.5755/j01.ee.31.1.24045

8. Bloch, C. (2007). Assessing recent developments in innovation measurement: The third edition of the Oslo Manual. Science and Public Policy, 34 (1), 23-34.

https://doi.org/10.3152/030234207X190487 
9. Brodowska-Szewczuk, J. (2019). Determinants of the development of enterprises' innovativeness in the aspect of competitiveness of the economy. Enterpreunership and Sustainability Issues, 7 (2), 1279-1295. http://doi.org/10.9770/jesi.2019.7.2(33)

10. Calantone, R. J. \& di Benedetto, C. A. (1990). Canonical Correlation Analysis of unobserved relationships in the new product process. R\&D Management, 20, 1, 3-23.

11. Cannas, M., Sergi, B. S., Sironi, E., \& Mentel, U. (2019). Job satisfaction and subjective wellbeing in Europe. Economics and Sociology, 12 (4), 183-196. doi:10.14254/2071-789X.2019/12-4/11

12. Cao, X., Ke, J., Sandstede, B., \& Luo, X. (2019). Time-dependent Canonical Correlation Analysis for multilevel time series. Preprint. Available at: https://www.biorxiv.org/ content/10.1101/650101v1.full.pdf

13. Caurkubule, Zh. L., Kenzhin, Zh. B. Bekniyazova, D.S., Bayandina, G.D., \& Dyussembekova, G. S. (2020). Assessment of competitiveness of regions of the Republic of Kazakhstan. Insights into Regional Development, 2 (1), 469-479. http://doi.org/10.9770/IRD.2020.2.1(6)

14. Čepel, M. (2019). Social and cultural factors and their impact on the quality of business environment in the SME segment. International Journal of Entrepreneurial Knowledge, 7 (1), 65-73. https://doi.org/10.2478/ijek-2019-0005

15. Cieślik, A., \& Michałek, J. J. (2018). Firm-level determinants of direct and indirect exports: Empirical evidence for C.E.E. and M.E.N.A. countries. Economic Research-Ekonomska Istraživanja, 31 (1), 982-996. https://doi.org/10.1080/ 1331677X.2018.1436452

16. CORE (2017). The CORE Team. The economy: Economics for the changing world. Oxford University Press, September 2017. http://www.core-econ.org/the-economy/book/text/0-3contents.html

17. Dos Santos, S. F. \& Brandi, H. S. (2014). A canonical correlation analysis of the relationship between sustainability and competitiveness. Clean Technologies and Environtal Policy, 16 (1), 1735-1746. https://doi.org/10.1007/s10098-014-0755-2

18. Dvorský, J., Petráková, Z., Ajaz Khan, K., Formánek, I., \& Mikoláš, Z. (2020). Selected aspects of strategic management in the service sector. Journal of Tourism and Services, 20 (11), 109-123. https://doi.org/10.29036/jots.v11i20.146

19. Eurostat (2019). Statistics. https://ec.europa.eu/eurostat/data/ statistics-a-z/ghij

20. Felstead, M. (2019). Cyber-physical production systems in Industry 4.0: smart factory performance, innovation-driven manufacturing process innovation, and sustainable supply chain networks. Economics, Management, and Financial Markets, 14 (4), 37-43. https://doi.org/10.22381/EMFM14420195

21. Fussler, C., \& James, P. (1996). Driving Eco-innovation: a breakthrough discipline for innovation and sustainability. London: Pitman Publishing

22. Fyliuk, H., Honchar, I., \& Kolosha, V. (2019). The interrelation between economic growth and national economic competitiveness: The Case of Ukraine. Journal of Competitiveness, 11 (3), 53-69. https://doi.org/10.7441/joc.2019.03.04 
23. Georgescu, I., \& Kinnunen, J. (2020). The digital effectiveness on economic inequality: a computational approach. In: Dima, A. M. \& D'Ascenzo, F. Business Revolution in a Digital Era. Springer Proceedings in Business and Economics. Springer Nature Switzerland AG. https://doi.org/10.1007/978-3-030-59972-0

24. Haller, A. (2020). From classical and neoclassical economic growth to degrowth in Europe. Challenges for public administration. Administratie si Management Public, 34, 150-170. https://doi.org/10.24818/amp/2020.34-9

25. Jafarnejad Chaghooshi, A., Soltani-Neshan, M. \& Moradi-Moghadam, M. (2015). Canonical correlation analysis between supply chain quality management and competitive advantages. Foundations of Management, 7, 83-92. https://doi.org/10.1515/fman-2015-0027

26. Janoskova, K., \& Kral, P. (2019). An in-depth analysis of the summary Innovation index in the V4 countries. Journal of Competitiveness, 11 (2), 68-83. https://doi.org/10.7441/joc.2019.02.05

27. Jašková, D. (2019). Assessment of social development in Slovakia in the context of human resources. Central European Journal of Labour Law and Personnel Management, 2 (2), 21-32. https://doi.org/10.33382/cejllpm.2019.03.02

28. Johnson, H. T., \& Kaplan, R. S. (1987) Relevance Lost: The Rise and Fall of Management Accounting. Boston: Harvard Business School Press.

29. Kachigian, S.K. (1991). Multivariate Statistical Analysis: A Conceptual Introduction. New York: Radius Press.

30. Kaplan, R. S., \& Norton, D. P. (1992). The Balanced Scoreboard Measures That Drive Performance. Harvard Business Review, 2, 71-92.

31. Kelić, I., Erceg, A., \& Čandrlić Dankoš, I. (2020). Increasing tourism competitiveness: Connecting Blue and Green Croatia. Journal of Tourism and Services, 20 (11), 132-149. https://doi.org/10.29036/jots.v11i20.138

32. Kinnunen, J., Androniceanu, A., \& Georgescu, I. (2019). The Role of Economic and Political Features in Classification of Countries-in-Transition by Human Development Index. Informatica Economica, 23 (4), 26-40. https://doi.org/10.12948/issn14531305/2 3.4.2019.03

33. Ključnikov, A., Belás, J., \& Smrčka, L. (2016). Risk-taking and Aggressiveness as the Significant Part of the Entrepreneurial Orientation of SMEs: Case of the Czech Republic. Polish Journal of Management Studies, 14 (1), 129-139. https://doi.org/10.17512/pjms.2016.14.1.12

34. Kozubikova, L., Kotaskova, A., Dvorsky, J., \& Kljucnikov, A. (2019). The impact of political factors' perception on suitability of international business environment: The case of startups. Economics and Sociology, 12 (1), 61-79. https://doi.org/10.14254/2071-789X.2019/12-1/3

35. Leković, B., Strugar Jelača, M., \& Slobodan M. (2019). Importance of innovative management practice: solution for challenges in business environment and performance in large organizations in Serbia. E\&M Economics and Management, 22(4), 68-83.

36. Lukiewska, K. (2019). Changes in the competitive position of the food industry in the European Union member states. Forum Scientiae Oeconomia, 7 (2), 71-87. https://doi.org/10.23762/FSO_VOL7_NO2_5 
37. Meyer, D. F., Masehla, T. M., \& Kot, S. (2017) The relationship between economic growth and economic development: A regional assessment in South Africa. Journal of Advanced Research in Law and Economics, 8 (4), 1377-1385. https://doi.org/10.14505/jarle.v8.4(26).38

38. Mikiashvili, N., \& Lobzhanidze, N., (2017). Green innovations and economic policy in small economies. Forum Scientiae Oeconomia, 5 (2), 29-40. https://doi.org/10.23762/fso_vol5no2_17_3

39. Mishchuk, H., \& Grishnova, O. (2015). Empirical study of the comfort of living and working environment Ukraine and Europe: comparative assessment. Journal of International Studies, 8 (1), 67-80. https://doi.org/10.14254/2071-8330.2015/8-1/6

40. Mura, L., Buleca, J., Hajduová, Z., \& Andrejkovič, M. (2015). Quantitative financial analysis of small and medium food enterprises in a developing country. Transformation in Business \& Economics, 14 (1), 212-224.

41. Nica, E. (2019). Cyber-physical production networks and advanced digitalization in industry 4.0 manufacturing systems: sustainable supply chain management, organizational resilience, and data-driven innovation. Journal of Self-Governance and Management Economics, 7 (3), 27-33. https://doi.org/10.22381/JSME7320194

42. OECD (2017). How's Life? Measuring Well-being. Paris: OECD Publishing.

43. Olšovská, A., Mura, L., \& Švec, M. (2016). Personnel management in Slovakia: An explanation of the latent issues. Polish Journal of Management Studies, 13 (2), 110-120.

44. Pavitt, K. (1984). Patterns of technical change: towards a taxonomy and a theory. Research Policy, 13, 343-374.

45. Piątkowski, M. J. (2020). Implementation of innovations in enterprises using the EU funds: A comparative analysis. Journal of International Studies, 13 (2), 109-126. https://doi.org/10.14254/2071- 8330.2020/13-2/8

46. Popescu, Gheorghe H. \& Ciurlău, F.C. (2019). Making decisions in collaborative consumption: digital trust and reputation systems in the sharing economy. Journal of Self-Governance and Management Economics, 7(1), 7-12. https://doi.org/10.22381/JSME71 20191

47. Porter, M. E. (1998). The Competitive Advantage of Nations. New York: The Free Press.

48. Porter, M.E. (1985). The Competitive Advantage Creating and Sustaining Superior Performance. New York: Free Press.

49. Razavi, S. M., Ghasemi, R., Abdullahi, B. \& Kashani, M. (2011). Relationship between technological readiness and innovation: a secondary analysis of countries global competitiveness. European Journal of Scientific Research, 59 (3), 318-328.

50. Schmookler, J. (1966). Invention and economic growth. Harvard: Harvard University Press.

51. Schumpeter, J. A. (1934). The theory of economic development: an inquiry into profits, capital, credit, interest and the business cycle, Harvard Economic Studies, Vol. 46, Harvard College, Cambridge, MA. Retrieved from: https://www.researchgate.net/publication/25606 0978_Schumpeter's_View_on_Innovation_and_Entrepreneurship

52. Schwab, K. (2019). The global competitiveness report 2019. Geneva, Switzerland: World Economic Forum. 
53. Sebestova, J., \& Sroka, W. (2020). Sustainable development goals and SME decisions: the Czech Republic vs. Poland. Journal of Eastern European and Central Asian Research, 7 (1), 39-50. https://doi.org/10.15549/jeecar.v7i1.418

54. Sharma, S. (1996). Applied Multivariate Techniques. Canada: John Wiley \& Sons Inc.

55. Sherry, A., \& Henson, R. K. (2005). Conducting and interpreting Canonical Correlation Analysis in personality research: a user-friendly primer. Journal of Personality Assessment, 84 (1), 37-48. https://doi.org/10.1207/s15327752jpa8401_09

56. Shkolnyk, I., Kozmenko, S., Kozmenko, O., \& Mershchii, O. (2019). The impact of the economy financialization on the level of economic development of the associate EU member states. Economics and Sociology, 1 (4), 43-58. https://doi.org/10.14254/2071-789X.2019/12-4/2

57. Šloga, H., \& Bezić, H. (2020). The relationship between innovative orientations and business performance in companies. Ekonomskamisaoipraksa / Economic Thought and Practice, 29 (1), 57-76.

58. Streimikiene, D. (2014). Comparative Assessment of Environmental Indicators of Quality of Life in Romania and Lithuania. Economics and Sociology, 7 (1), 11-21. https://doi.org/10.14254/2071-789X.2014/7-1/2

59. Trettin, C., Lazaroiu, G., Grecu, I., \& Grecu, G. (2019). The social sustainability of citizencentered urban governance networks: sensor-based big data applications and real-time decision-making. Geopolitics, History, and International Relations, 11 (2), 27-33. https://doi.org/10.22381/GHIR11220194

60. UNDP (2019a). Human Development Data (1990-2018). http://hdr.undp.org/en/data

61. UNDP (2019b). Human Development Report 2019. New York: United Nations Development Programme.

62. Vasilyeva, T., Lyeonov, S., Adamičková, I., \& Bagmet, K. (2018). Institutional Quality of Social Sector: The Essence and Measurements. Economics and Sociology, 11 (2), 248-262. https://doi.org/10.14254/2071-789X.2018/11-2/17

63. Vlacseková, D., \& Mura, L. (2017). Effect of motivational tools on employee satisfaction in small and medium enterprises. Oeconomia Copernicana, 8 (1), 111-130. https://doi.org/10.24136/ oc.v8i1.8

64. Vetráková, M., \& Smerek, L. (2019). Competitiveness of Slovak enterprises in Central and Eastern European Region. E $\mho M$ Economics and Management, 22 (4), 36-50. http://doi.org/10.15240/tul/001/2019-4-003

65. Wasiluk, A., \& Ginevičius, R. (2020). Pro-innovative motives for establishing cooperation by enterprises: An empirical study in Poland. Economics and Sociology, 13 (2), 258-278. https://doi.org/10.14254/2071-789X.2020/13-2/17

66. Wenzel, L., \& Wolf, A. (2016), Towards a new measure of a country's competitiveness: applying canonical correlation. Competitiveness Review, 26 (1), 87-107. https://doi.org/10.1108/CR-09-2014-0030

67. World Economic Forum (2019). The Global Competitiveness Index 4.02019 Dataset. Retrieved from: http://www3.weforum.org/docs/WEF_GCI_4.0_2019_Dataset.xlsx 
68. Zeibote, Z.; Volkova, T., \& Todorov, K. (2019). The impact of globalization on regional development and competitiveness: cases of selected regions. Insights into Regional Development, 1 (1), 33-47. https://doi.org/10.9770/ird.2019.1.1(3)

\section{Contact information}

Ane-Mari Androniceanu, Ph.D. Candidate

Bucharest University of Economic Studies

Doctoral School of Management

Bucharest, 6 PiataRomana, 010374

Romania

E-mail: ane.androniceanu.drd@gmail.com

ORCID: 0000-0002-1441-4496

Jani Kinnunen

Abo Akademi University

Department of Information Systems

Turken

Finland

E-mail:jani.kinnunen@abo.fi

ORCID: 0000-0002-0154-6617

Irina Georgescu, Ph.D.

Bucharest University of Economics

Department of Informatics and Economic Cybernetics

Romania

E-mail:irina.georgescu@csie.ase.ro

ORCID:0000-0002-8536-5636

Prof. Armenia Androniceanu, Ph.D.

Bucharest University of Economic Studies

International Centre for Public Management, 11, Tache Ionescu

Romania

University of Social Sciences, 9 Sienkiewicza St. 90-113, Lodz.

Poland

E-mail:armenia.androniceanu@man.ase.ro

ORCID: 0000-0001-7307-5597 